\title{
Risk factors in chronic obstructive pulmonary malfunction and "chronic bronchitis" symptoms in Beijing district: a joint study between Japan and China
}

\author{
SEIYA YAMAGUCHI, ${ }^{1}$ KATSUMI KANO, ${ }^{1}$ NOBUHIRO SHIMOJO, ${ }^{1}$ KENICHI \\ SANO,${ }^{1}$ XIPINGXU, ${ }^{1}$ HIROKATSUWATANABE, ${ }^{1}$ MASAAKIKAMEYAMA, ${ }^{3}$ MARIA \\ JOSESANTAMARIA, ${ }^{1}$ SHIJIELIU, ${ }^{2}$ LIHUA WANG,${ }^{2}$ YUDECHEN,${ }^{2}$ WENZHISONG,${ }^{2}$ \\ FUSHENG MA, ${ }^{2}$ AND LIN LU ${ }^{2}$ \\ From 'The Institute of Community Medicine, The University of Tsukuba, Tsukuba City, Ibaraki 305, Japan; \\ ${ }^{2}$ Beijing Medical University, School of Public Health, Beijing, People's Republic of China; and ${ }^{3}$ The Institute of \\ Medicine, The University of Tsukuba, Tsukuba City, Ibaraki 305, Japan
}

ABSTRACT A cross sectional study of risk factors in respiratory diseases was carried out in August 1986 , in Beijing, China. Inhabitants $\geqslant 40$ years old were selected at random from a rural area, a residential area and an industrial area, using a two stage sampling method. The analysis presented here is based on the sample population of adults who (1) were prepared to be interviewed, using the British Medical Research Council's questionnaire translated into Chinese $(n=3423)$ and $(2)$ had lung function measurements at the same time $(n=3373)$. Obstructive lung disease was defined as forced expiratory volume in $1 \mathrm{~s}\left(\mathrm{FEV}_{1}\right)$ less than $68 \%$ of forced vital capacity (FVC). Seven variables were considered as potential risk factors or confounding factors: area of residence, sex, age, cigarette smoking, history of respiratory disease, socio-economic status and familial component. A modified binary variable regression method developed by Feldstein was used for the adjustment of rate ratios. The adjusted prevalence of obstructive lung disease was highest in the rural area and lowest in the residential area(s). An increase in age, cigarette smoking, low socio-economic status and positive history of respiratory diseases were associated with significantly higher rates of impaired pulmonary function. The other measured factors did not appear to be related to impaired pulmonary function.

China aspires to be an industrialised nation and therefore its industrial activities are growing steadily. This is resulting in a rapid change in the environment, with widespread increase in pollutants. Data reported by the Global Environmental Monitoring Systems ${ }^{1}$ (GEMS) have indicated, as expected, that levels of outdoor air pollutants, such as suspended particulate matter, sulphur dioxide, carbon monoxide, etc, are much lower in rural areas than in urban residential areas, and these pollutants are widely believed to be the major cause of "chronic bronchitis".

Nevertheless the adjusted rate of chronic bronchitis was no lower in rural areas than it was in cities. This may partly be accounted for by the fact that cigarette smoking, past history of respiratory disease, and socio-economic status are associated with increased adjusted rates of chronic bronchitis, but it was also suggested $^{1}$ that there are different risk factors in urban and rural populations which were not disclosed by the study. We have illustrated this possibility in fig. 1 , showing how such risk factors may belong to different but overlapping domains. The study described here was undertaken in an attempt to identify those factors which might be responsible for chronic bronchitis in different areas of Beijing district, which includes Beijing itself, an industrial city with a population of 9.8 million, surrounded by a suburban area of 4.18 million population, and an extensive rural area.

\section{Methods}

THE AREA

Beijing lies between latitudes $38.8^{\circ}$ and $41.05^{\circ} \mathrm{N}$ and between longitudes $115.25^{\circ} \mathrm{W}$ and $117.30^{\circ} \mathrm{E}$. Spring weather is dry and windy. Summer is hot and may be rainy. Autumn is cool and pleasant, and winter is cold and dry. Average annual temperature is $12^{\circ} \mathrm{C}$. Average temperature in January is $-4^{\circ} \mathrm{C}$ and in July, $26^{\circ} \mathrm{C}$.

Figure 2 shows a map of Beijing and its neighbourhood. Areas 1, 2 and 3 on the map form the 

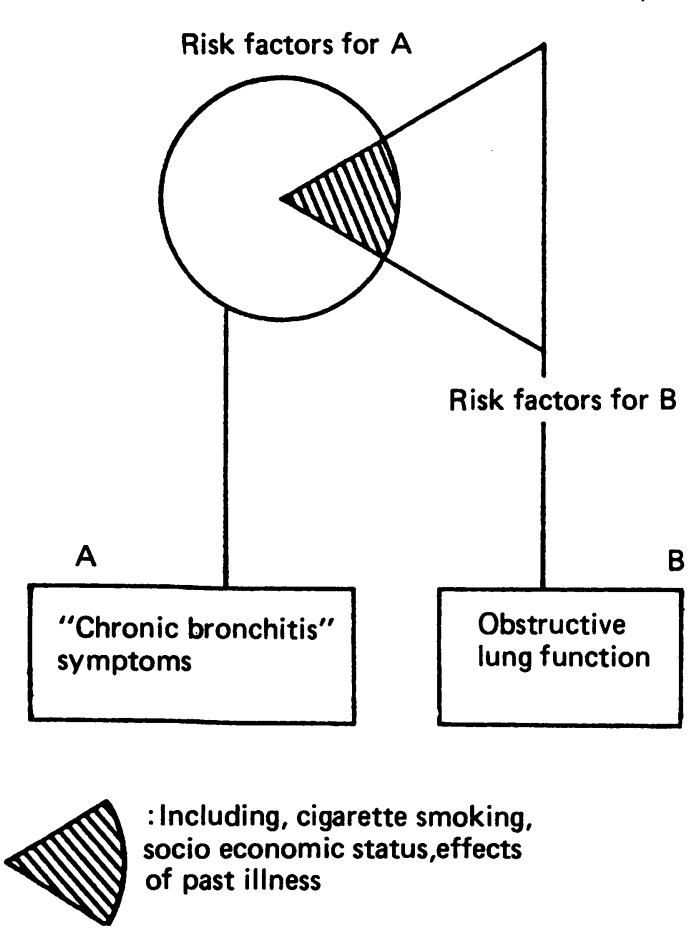

: Including, cigarette smoking, socio economic status, effects of past illness

\section{Fig 1 Illustration of the different risk ractors}

study areas. These were selected at random from among various suitable target areas in urban and rural parts of Beijing district, so as to provide suburban residential, industrial, and rural population study groups.

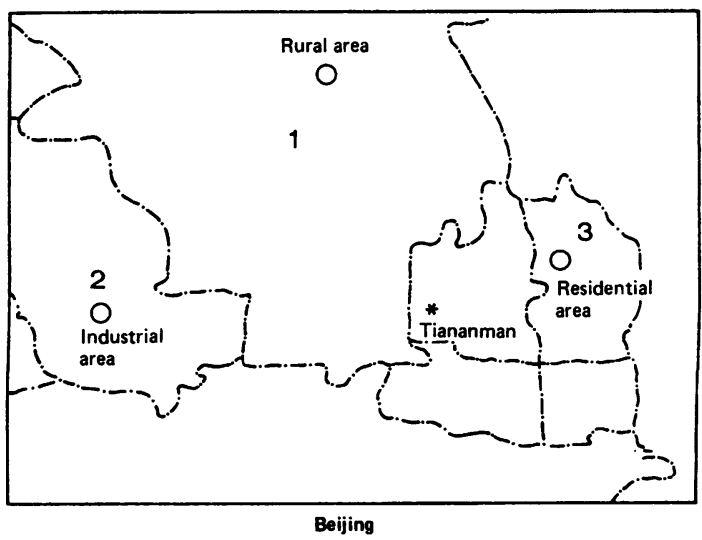

Fig 2 Map of Beijing district

THE STUDY

The Japan-China joint study began in the summer of 1985. The feasibility study and the development of the protocol are the joint work of epidemiologists in the two countries. The field study was carried out in August 1986, after a year of preparation.

The sample population was selected at random from residents aged 40 years and over who had been living in the selected areas for more than 6 months per year for at least the preceding 5 years. The basic population used for the sampling was obtained from the Registration List for the National Census which was held on 1st July 1982. At the time of sampling, people who had moved to other districts or who had died were excluded automatically.

Table 1 Numbers of samples in each age, sex and area $(n=3600)$

\begin{tabular}{|c|c|c|c|c|c|c|c|c|}
\hline & \multicolumn{2}{|c|}{ Residential area } & \multicolumn{2}{|c|}{ Rural area } & \multicolumn{2}{|c|}{ Industrial area } & \multicolumn{2}{|l|}{ Total } \\
\hline & Male & Female & Male & Female & Male & Female & Male & Female \\
\hline Age (yr): $\begin{array}{rl} & 40-49 \\
50-59 & 60+\end{array}$ & $\begin{array}{l}191 \\
217 \\
168\end{array}$ & $\begin{array}{l}195 \\
259 \\
170\end{array}$ & $\begin{array}{l}206 \\
216 \\
176\end{array}$ & $\begin{array}{l}274 \\
176 \\
152\end{array}$ & $\begin{array}{l}207 \\
269 \\
121\end{array}$ & $\begin{array}{r}283 \\
233 \\
87\end{array}$ & $\begin{array}{l}604 \\
702 \\
465\end{array}$ & $\begin{array}{l}752 \\
668 \\
409\end{array}$ \\
\hline Total & 576 & 624 & 598 & 602 & 597 & 603 & 1771 & 1829 \\
\hline
\end{tabular}

Table 2 Age, sex and residential distribution of subjects responding to Medical Research Council Questionnaire ( $n=3423$ )

\begin{tabular}{|c|c|c|c|c|c|c|c|c|}
\hline & \multicolumn{2}{|c|}{ Residential area } & \multicolumn{2}{|c|}{ Rural area } & \multicolumn{2}{|c|}{ Industrial area } & \multicolumn{2}{|l|}{ Total } \\
\hline & Male & Female & Male & Female & $\overline{\text { Male }}$ & Female & Male & Female \\
\hline 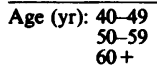 & $\begin{array}{l}168 \\
191 \\
148\end{array}$ & $\begin{array}{l}171 \\
228 \\
149\end{array}$ & $\begin{array}{l}201 \\
211 \\
172\end{array}$ & $\begin{array}{l}267 \\
172 \\
148\end{array}$ & $\begin{array}{l}207 \\
268 \\
121\end{array}$ & $\begin{array}{r}282 \\
232 \\
87\end{array}$ & $\begin{array}{l}576 \\
670 \\
441\end{array}$ & $\begin{array}{l}720 \\
632 \\
384\end{array}$ \\
\hline Total & 507 & 548 & 584 & 587 & 596 & 601 & 1687 & 1736 \\
\hline
\end{tabular}

Table 3 Age, sex and residential distribution of subjects having lung function tests ( $n=3373$ )

\begin{tabular}{|c|c|c|c|c|c|c|c|c|}
\hline & \multicolumn{2}{|c|}{ Residential area } & \multicolumn{2}{|c|}{ Rural area } & \multicolumn{2}{|c|}{ Industrial area } & \multicolumn{2}{|l|}{ Total } \\
\hline & Male & Female & Male & Female & Male & Female & Male & Female \\
\hline Age (yr): $\begin{array}{rl} & 40-49 \\
50-59 & 60+\end{array}$ & $\begin{array}{l}168 \\
190 \\
146\end{array}$ & $\begin{array}{l}170 \\
227 \\
148\end{array}$ & $\begin{array}{l}201 \\
210 \\
171\end{array}$ & $\begin{array}{l}262 \\
168 \\
142\end{array}$ & $\begin{array}{l}203 \\
263 \\
118\end{array}$ & $\begin{array}{r}277 \\
225 \\
84\end{array}$ & $\begin{array}{l}572 \\
663 \\
435\end{array}$ & $\begin{array}{l}709 \\
620 \\
374\end{array}$ \\
\hline Total & 504 & 545 & 582 & 572 & 584 & 586 & 1670 & 1703 \\
\hline
\end{tabular}


We randomly selected 3600 subjects, 1200 from each area (table 1), and tables 2 and 3 show the distribution of the sample subjects who were willing to be investigated, according to sex, age and living area. In the analysis which follows the subjects in the rural area are considered to be the control group.

The interviewers were selected from the students of Beijing Medical School. The questionnaire (British Medical Research Council respiratory questionnaire, 1976 version $^{2}$ ) was translated into Chinese and its validity was tested as suggested. ${ }^{2} 3$ The MRC instructions and recorded tape cassettes were employed for the training of interviewers.

Questionnaire evalution-Socio-economic status was defined by ocupation, final grade of education, level of income, household facilities, and number of family members per room. The final total score was then classified as either high or low. To evaluate possible hereditary factors, parents' respiratory diseases (chronic bronchitis, bronchial asthma, emphysema) were recorded. Questions 3 and 6 of the MRC questionnaire were used to evaluate current symptoms of chronic bronchitis:

Do you cough like this $(\mathrm{Q} 3)$ /bring up phlegm like this (Q6) on most days for as much as 3 months each year (in the winter)?

Respiratory function tests-The instrument used to test lung function was the Autospirometer AS-300 (Minato Ikagaku), which had been tested previously for accuracy using standard calibration. To evaluate "obstruction" we used forced expiratory volume in 1s $\left(F E V_{1}\right)$. So that the results would be comparable with the data of Menkes et al, ${ }^{4}$ we considered airways obstruction to be present if the $\mathrm{FEV}_{1}$ was less than $68 \%$ of forced vital capacity.

Of the 3600 subjects identified, $3423(95.1 \%)$ were interviewed and $3373(95 \%)$ had lung function tests. We rejected 50 subjects who were considered unreliable.

The results of the study were analysed by a modified version of Feldstein's binary variable multiple regression analysis. ${ }^{4}$

GLOBAL ENVIRONMENTAL MONITORING SYSTEM We also report some results from the GEMS data collection to complement the findings of our binational study. GEMS was initiated in 1974 by the United Nations Environmental Protection Programme and is carried out by the World Health Organisation. ${ }^{1}$ The setting up of the monitoring station and measurement of environmental pollutants was started on January 1st 1981, at Beijing, Shanghai, Shenyang, Xi'An and Guangzhoh. The monitoring stations around these five cities have been positioned in representative areas. In Beijing the areas selected for monitoring were industrial, commercial, suburban residential and rural (control) areas.
Results of measurements of air pollutants are reported for 24 samples per day, 12 days per month, at each station (70 000 samples measured and reported since 1981).

\section{Results}

We analysed adjusted rates of seven risk factors (area of residence, age, sex, socio-economic status, history of past chest illness, parental history of chest illness, smoking) and investigated the association between these factors and the occurrence of chronic bronchitis symptoms and objective evidence of obstructive airways disease.

Table 4 shows the adjusted rate ratio of risk factors in relation to chronic bronchitis symptoms. The most important factor was a past history of respiratory illness in the sample population, followed by smoking habits, socio-economic status, and parental history of respiratory disease.

Table 4 Adjusted rate ratio of positive answers to questions 3 and 6 of $M R C$ respiratory questionnaire (see text for details) between risk group $(A)$ and control group (B)

\begin{tabular}{|c|c|c|c|}
\hline$A / B$ & Adjusted rate & Ratio & Test \\
\hline $\begin{array}{l}\text { Past illness/none } \\
\text { Smoker } 10(+) \text { day/never } \\
\text { Smoker } 1-9 \text { day/never } \\
\text { Industrial area/residential area } \\
\text { Rural area/residential area } \\
\text { Ex-smoker/never } \\
\text { Socio-economic status low/high } \\
\text { Parental history of chronic }\end{array}$ & $\begin{array}{l}22 \cdot 18 / 5 \cdot 88 \\
18 \cdot 95 / 8 \cdot 52 \\
17 \cdot 88 / 8 \cdot 52 \\
16 \cdot 40 / 9 \cdot 08 \\
14 \cdot 72 / 9 \cdot 08 \\
12 \cdot 55 / 8.52 \\
16 \cdot 47 / 11 \cdot 89\end{array}$ & $\begin{array}{l}3 \cdot 77 \\
2 \cdot 22 \\
2 \cdot 10 \\
1.81 \\
1.62 \\
1.47 \\
1 \cdot 39\end{array}$ & $\begin{array}{l}t \\
t \\
t \\
\text { NS } \\
\text { NS } \\
+\end{array}$ \\
\hline $\begin{array}{l}\text { respiratory disease }+1- \\
\text { Age } 60(+) / 40-49 \\
\text { Age } 40-50 / 50-59 \\
\text { Female/male }\end{array}$ & $\begin{array}{l}16 \cdot 47 / 12 \cdot 30 \\
14 \cdot 89 / 13 \cdot 55 \\
13 \cdot 55 / 12 \cdot 70 \\
13 \cdot 62 / 13 \cdot 48\end{array}$ & $\begin{array}{l}1 \cdot 34 \\
1 \cdot 10 \\
1 \cdot 07 \\
1 \cdot 01\end{array}$ & $\begin{array}{l}\dagger \\
\text { NS } \\
\text { NS } \\
\text { NS }\end{array}$ \\
\hline Ratio $=\frac{\text { adjusted rate } \mathbf{A}}{\text { adjusted rate } B}$ & & & \\
\hline
\end{tabular}

Table 5 shows the adjusted rate ratio of risk factors in relation to obstructive lung function test results. The strongest influence was rural area versus suburban residential area (greater risk in rural area), followed by a history of past respiratory illness, age

Table 5 Adjusted rate ratio (see table 4) of evidence of airways obstruction ( $\left.F E V_{1}\right)$ between risk group $(A)$ and control group (B)

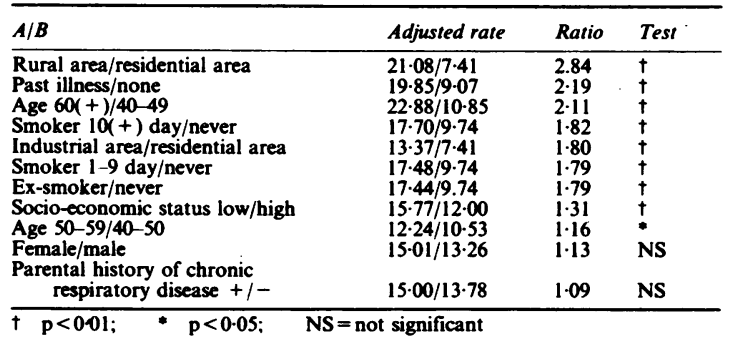


(60 years or over), and smoking. Table 6 summarises the risk factors for bronchitis symptoms and obstructive respiratory function tests.

Table 6 Association between risk factors and "chronic bronchitis" symptoms or "obstruction"

\begin{tabular}{|c|c|c|c|}
\hline & & $\begin{array}{l}\text { "Chronic bronchitis" } \\
\text { symptoms } \\
\text { Adjusted rate }\end{array}$ & $\begin{array}{l}\text { "Obstruction" } \\
\text { Adjusted rate }\end{array}$ \\
\hline Area: & $\begin{array}{l}\text { residential } \\
\text { rural } \\
\text { industrial }\end{array}$ & $\begin{array}{r}9 \cdot 08 \\
14 \cdot 72 \\
16 \cdot 40\end{array}$ & $\begin{array}{l}7 \cdot 41^{\mathrm{ab}} \\
21 \cdot 04^{\mathrm{ac}} \\
13 \cdot 37^{\mathrm{bc}}\end{array}$ \\
\hline Sex: & $\begin{array}{l}\text { male } \\
\text { female }\end{array}$ & $\begin{array}{l}13.48 \\
13.62\end{array}$ & $\begin{array}{l}13.26 \\
15.01\end{array}$ \\
\hline Age: & $\begin{array}{l}40- \\
50- \\
60+\end{array}$ & $\begin{array}{l}13 \cdot 55 \\
12 \cdot 70 \\
14 \cdot 89\end{array}$ & $\begin{array}{l}10 \cdot 53^{\mathrm{ad}} \\
12 \cdot 24^{\mathrm{db}} \\
22 \cdot 88^{\mathrm{ab}}\end{array}$ \\
\hline Socio-eco & $\begin{array}{l}\text { c score: } \\
\text { High } \\
\text { Low }\end{array}$ & $\begin{array}{l}11.89^{a} \\
16.47^{a}\end{array}$ & $\begin{array}{l}12 \cdot 00^{\mathrm{a}} \\
15 \cdot 77^{\mathrm{a}}\end{array}$ \\
\hline \multicolumn{4}{|c|}{$\begin{array}{r}\text { Past Chest Illness: } \\
\text { Yes } \\
\text { No }\end{array}$} \\
\hline Parental h & $\begin{array}{l}\text { y of respirat } \\
\text { Yes } \\
\text { No }\end{array}$ & $\begin{array}{l}16 \cdot 47^{\mathrm{a}} \\
12 \cdot 30^{\mathrm{a}}\end{array}$ & $\begin{array}{l}15 \cdot 00 \\
13 \cdot 78\end{array}$ \\
\hline Smoking: & $\begin{array}{l}\text { never } \\
\text { ex-smoker } \\
1-9 \\
10+\end{array}$ & $\begin{array}{l}8.52^{\mathrm{abd}} \\
12 \cdot 55^{\mathrm{d}} \\
17 \cdot 88^{\mathrm{b}} \\
18.95^{\mathrm{a}}\end{array}$ & $\begin{array}{l}9 \cdot 74^{\mathrm{abc}} \\
17 \cdot 44^{\mathrm{a}} \\
17 \cdot 48^{\mathrm{b}} \\
17 \cdot 70^{\mathrm{c}}\end{array}$ \\
\hline
\end{tabular}

In each category aa, bb, cc p $<0.01 ;$ dd $p<0.05$

\section{ENVIRONMENTAL STUDY}

Figures 3-5 show the 1981 trends of Beijing monthly averages in the amounts of sulphur dioxide, carbon monoxide, and suspended particulate matter (not available from January to March), together with environmental temperatures. These data, which appeared in August 1983, are the only ones which have been published as yet. The monthly variations in pollutants were not reflected in any changes in the respiratory health of Beijing residents in our study, neither did we show any significant differences in bronchitic symptoms or airways obstruction which could be attributed to outdoor-indoor pollution differences or to personal exposure to nitrous oxide during the summer months.

\section{Discussion}

Our results suggest that there is an aetiological difference between the objective finding of obstructive airways disease and the occurrence of symptoms of chronic bronchitis. As shown in tables 4-6, although there was a strong association of both "chronic bronchitis" and "obstruction" with past respiratory illness, as well as with smoking and social factors, on the other hand age, area and familial factors contributed to only one of these outcome variables (table 6). Thus the adjusted rate of obstructive lung function test results was significantly higher in the rural areas than in the residential and industrial areas, but this was not true of chronic bronchitis symptoms.
The adjusted rate of "obstruction" was also higher in the older age group (60 years or more) than in the other age groups, whereas the adjusted rate of chronic bronchitis symtoms showed no statistical difference between age groups.

Concepts of chronic bronchitis and obstructive lung disease have been revised from time to time, and this has been emphasised by Fletcher and co-workers in their work on the aetiology of these disorders. ${ }^{5-9}$ For example, these authors have suggested that smoking, an important contributor to respiratory pathology, may be implicated in the development of "bronchitic" symptoms and clinical obstructive airways disease through different mechanisms. The influence of past respiratory illness may also operate in different ways as a factor in bronchitic symptoms and "obstruction".

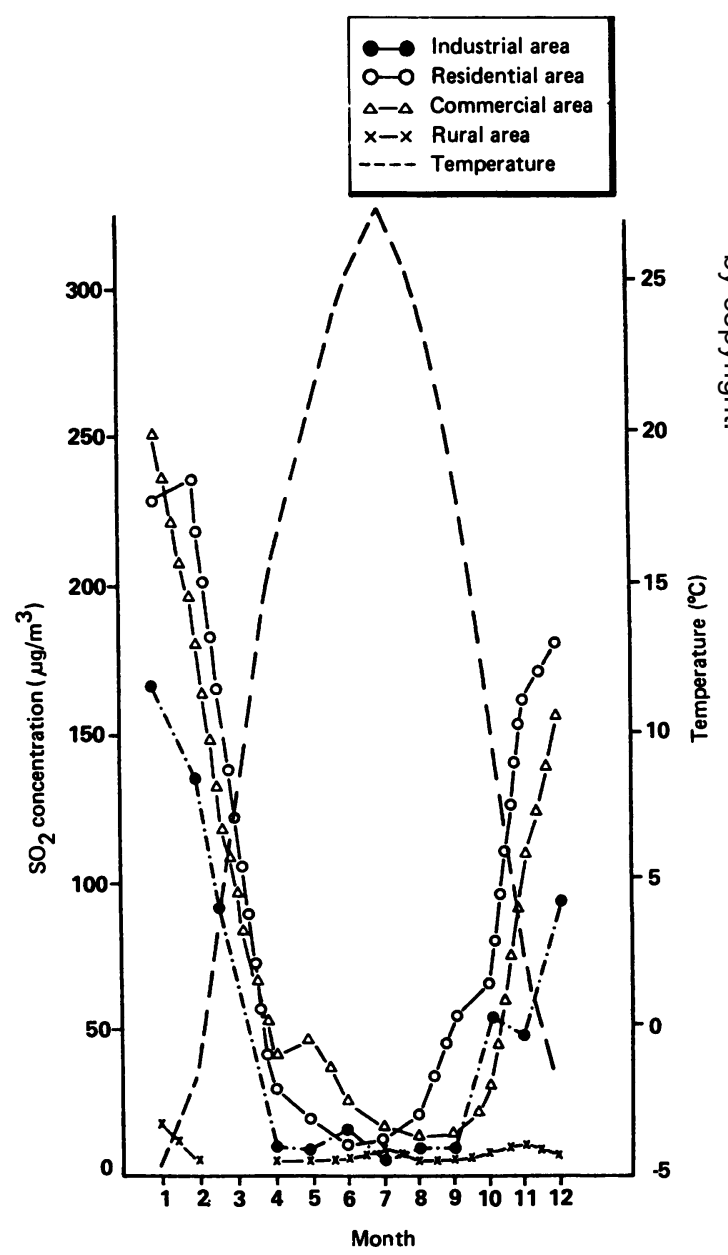

Fig 3 Annual Trend of monthly average sulphur dioxide concentration (1981). 


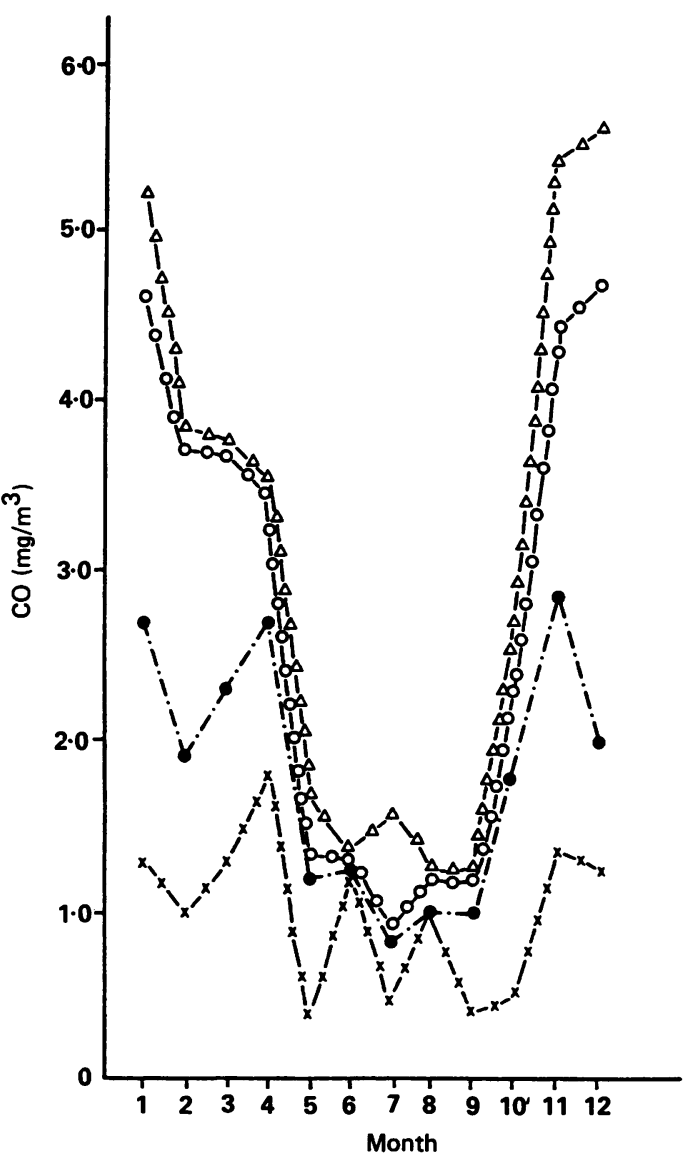

Fig 4 Annual trend of monthly average carbon monoxide (CO) concentration in Beijing distinct (1981)

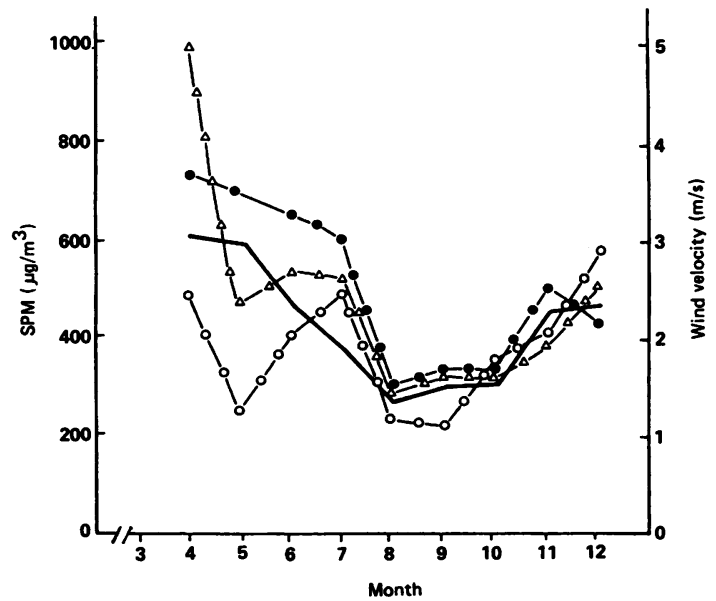

Fig 5 Annual trend of monthly average suspended particulate matter (SMP) in Beijing distinct (1981)
If these risk factors had all originated from the same reservoir, statistical analysis of their contributing power should have produced the same effect in the same manner on the residents in a particular area, taking into account their lifestyles, social status and age group. ${ }^{10}$

So far as further research is concerned, we feel there is a need to extend the area of study and identify specific risk factors other than those studied in the current project, especially those relating to genetic influences, ${ }^{11} 12$ the effects of personal exposure and indoor environmental characteristics, ${ }^{13}$ socioeconomic characteristics and age factors. ${ }^{14}$

We are grateful for the substantial support given by Beijing Medical University and the University of Tsukuba.

Address for correspondence and reprints: Professor S Yamaguchi, The University of Tsukuba, Institute of Community Medicine, Tsukuba City, Ibaraki, 305, Japan.

\section{References}

${ }^{1}$ Global Environmental Monitoring System. Beijing: Section of Preventive Medicine, Department of Health, People's Republic of China, 1983.

2 Medical Research Council Committee on Research into Chronic Bronchitis. Questionnaire on respiratory symptoms and Instructions to interviewers. London: Medical Research Council, 1976.

${ }^{3}$ Holland WW, Ashford JR, Colley JRT, Morgan DC, Pearson NJ. A comparison of two respiratory symptoms questionnaires: $\mathrm{Br} J$ Prev Soc Med 1966; 20: 76-96.

${ }^{4}$ Menkes HA, Cohen BH, Levy DA, Kreis K, Permutt S, Tielsh $J$. Genetic factors in chronic obstructive lung disease, Bull Europ Physiopathol Respir 1980: 16: 357-64.

${ }^{5}$ Fletcher CM, Elmes PC, Fairbairn AS, Wood CH. The significance of respiratory symptoms and the diagnosis of chronic bronchitis in a working population. Br Med J 1959; ii: $257-66$.

${ }^{6}$ Terminology, definitions, and classification of chronic pulmonary emphysema and related conditions. A report of the conclusions of a Ciba Guest Symposium prepared by C M Fletcher. Thorax 1959; 14: 286-97.

${ }^{7}$ Fletcher CM. Definition and classification of chronic bronchitis: British Medical Research Council: Lancet 1965; i: 775-9.

${ }^{8}$ Fletcher CM, Peto R. The natural history of chronic airflow obstruction. Br Med J 1977; i: 1645-8.

9 Fletcher CM, Pride NB. Definition of emphysema, chronic bronchitis, asthma, and airflow obstruction: 25 years on from the Ciba symposium. Thorax 1984; 39: 81-5.

${ }^{10}$ Colley JRT, Holland WW. Social and environmental factors in respiratory disease. Arch Environ Health 1967; 14: $157-61$.

${ }^{11}$ Cohen BH, Menkes HA, Bias WB, et al. Multiple factors in airway obstruction. Chest 1980; 77: 257-9. 
${ }^{12}$ Melia RJW, Florey CduV, Darby SC, Palms ED Goldstein BD. Differences in $\mathrm{NO}_{2}$ levels in kitchen with gas or electric cookers. Atmospheric Environment 1978; 12: $1379-81$.

${ }^{13}$ Cooley JRT, Douglas JWB, Reid DD. Respiratory diseases in young adults: influence of early childhood lower respiratory tract illness, social class, air pollution and smoking. $\mathrm{Br}$ Med J 1973; iii: 195-8.
${ }^{14}$ Holland WW, Colley JRT, Leeder SR, Corkhill R, Halil T. Epidemiologic approach of chronic bronchitis and precursory symptoms in childhood. Rev Fr Mal Respir 1977; 5: 87-94. 